\title{
Meningkatkan Kreativitas Seni Melalui Permainan Kolase Ampas Kelapa Anak Usia Dini di PAUD Al-Faiz Kota Langsa
}

\author{
Nina Rahayu \\ IAIN Langsa \\ nina10rahayu@iainlangsa.ac.id
}

\begin{abstract}
The problem on this study is that it is still lack of child creativity particularly in the arts. This can be seen from children who are not yet able to discriminate color and name color precisely as well as the use of less supportive game media in the development of child creativity. The purpose of the study was to figure out how to increase child art creativity through coconut amply collage games. The type of research used is qualitatively descriptive. Paud Al-Faiz's child research subject Paya Bujok Tunong Langsa numbered 10 group B children and research objects increased creativity through coconut dregs games. The instruments used on research through observation, interviews and documentation. As for the research results in this study that is, there is an increase in child art creativity while playing collage game. $90 \%$ of children who have started to be able to work on activities according to teacher intruction and are able to work according to indicators.
\end{abstract}

Keyword, Art Creativity, Coconut Dregs Collage, Early Childhood

\begin{abstract}
Abstrak
Permasalahan pada penelitian ini yaitu masih kurangnya kreativitas anak khususnya dalam bidang seni. Hal ini dapat dilihat dari anak yang belum mampu membedakan warna dan menyebutkan warna dengan tepat serta penggunaan media permainan yang kurang mendukung dalam perkembangan kreativitas anak. Tujuan penelitian ini adalah Untuk mengetahui bagaimana peningkatan kreativitas seni anak melalui permainan kolase ampas kelapa. Jenis penelitian yang digunakan yaitu kualitatif dekskriptif. Subjek penelitian anak Paud Al-Faiz Desa Paya Bujok Tunong Langsa berjumlah 10 anak kelompok B dan objek penelitian meningkatkan kreativitas melalui permainan ampas kelapa. Instrument yang digunakan pada penelitian melalui observasi, wawancara dan dokumentasi. Adapun hasil penelitian dalam penelitian ini yaitu terdapat peningkatan kreativitas seni anak saat memainkan permainan kolase. 90\% anak yang sudah mulai mampu mengerjakan kegiatan sesuai intruksi guru dan mampu mengerjakan sesuai dengan indikator.
\end{abstract}

Kata Kunci, Anak Usia Dini, Kreativitas Seni, Kolase Ampas Kelapa 


\section{A. Pendahuluan}

Anak usia dini merupakan kelompok anak yang berada pada proses pertumbuhan dan perkembangan yang unik. Dimana tiap anak- anak memiliki pola pertumbuhan dan perkembangan, intelegensi, sosial emosional, bahasa dan komunikasi sesuai tingkat pertumbuhan dan perkembangan. Seseuai dengan keunikan dan pertumbuhan anak usia dini sehingga penyelenggaraan disesuaikan dengan tahap-tahap perkembangan yang dilalui anak. Salah satu aktivitas sehari-hari anak dalam ruang lingkup pembelajarannya dapat dilakukan melalui bermain (Mulyasa, 2012).. Bermain merupakan kegiatan pembelajaran anak usia dini yang di tunjukkan melalui perbuatan tingkah laku dalam kehidupan sehari-hari. Melalui permainan anak mempelajari hal-hal yang belum diketahuinya. Sehingga bermain memiliki kedudukan yang paling penting dalam lingkungan anak (M. Fadhillah: 2017). Dalam permainan juga terkandung nilai kegembiraan yang memungkinkan anak berkhayal seperti dokter, pilot, guru serta berpetualang (Moeslichatoen: 2014).

Docket dan Fleer dalam (Sujiono, 2010) menyebutkan bermain merupakan kebutuhan bagi anak karena melalui anak akan memperoleh pengetahuan dan mengembangkan kemampuan dirinya. Bermain Menurut Mursid (2015) kreativitas seni merupakan sarana dalam pengembangan kreativitas yang merupakan sebuah karya yang di ciptakan dan memberikan sebuah keindahan bagi yang melihatnya.

Pengembangan kreativitas anak usia dini dalam pembelajaran harus menyenangkan dan menarik agar anak mudah dalam mencapai tujuan pembelajarannya. Kreativitas anak adalah kemampuan untuk menghasilkan sesuatu yang baru atau berbeda dari yang sudah ada. Kreativitas anak usia dini juga merupakan kreativitas alamiah yang dibawa dari sejak lahir dan merupakan kemampuan untuk menghasilkan pemikiran-pemikiran asli, tidak biasa dan fleksibel dalam merespon serta serta mengembangkan pemikiran (Supriyenti, 2013). 
Permasalahan yang dihadapi anak kelompok B di Paud AL-Faiz Kota Langsa adalah kurang berkembangnya kreativitas seni mereka. Hal ini ditandai dengan masih banyak anak yang masih belum dapat membedakan warna salah menyebutkan nama warna. Selain itu masih kurang antusias anak dalam belajar. Hal ini bisa disebabkan karena metode pembelajaran yang kurang menarik, alat pembelajaran yang kurang mendukung, dan kurangnya kreativitas guru dalam menyampaikan bahan ajar sehinga anak kurang berminat dan tidak antusias memperhatikan apa yang disampaikan.

Penggunaan kolase pada pembelajaran merupakan satu alternatif unuk permasalahan di atas agar memingkatkan kreativitas anak usia dini. Kolase adalah karya seni rupa dua dimensi yang menggunakan berbagai macam paduan bahan yang ditempelkan pada sebuah gambar dan dapat menghasilkan karya cipta seni yang menarik dan unik selama bahan tersebut dapat dipadukan dengan beberapa bahan dasar. Dalam proses pembuatan karya kolase dilakukan dengan cara memadukan barang-barang yang terdiri dari benda yang berbeda sehingga menjadi sebuah karya melalui teknik assembling (dengan dilem, las, dan paku) agar dapat menyatu. Permainan kolase dapat meningkatkan kreativitas seni anak usia dini (Mursid, 2015). Penelitian ini bertujuan untuk mnegetahui bagaimana peningkatan kreativitas anak melalui permainan kolase ampas kelapa di Paud Al-Faiz Kota Langsa.

\section{B. Metode}

Jenis penelitian dalam penelitian ini deskriptif kualitatif. Penelitian kualitatif merupakan sebuah penelitian yang berkaitan dengan fenomena alam dan masalah yang terjadi dalam ruang lingkup kehidupan (Noor, 2016). Fokus penelitian ini terkait peningkatan kreativitas seni anak usia dini melalui permainan kolase ampas kelapa. Subjek dari penelitian ini siswa Paud Al-Faiz Kota Langsa kelompok B berjumlah 10 siswa dengan 4 laki-laki dan 6 perempuan. Selanjutnya data yang diperoleh dianalisis untuk 
memperoleh jawaban dari rumusan masalah. Pada penelitian ini terdapat beberapa tahapan untuk mengumpulkan dan menganalisis data diantaranya: reduksi data, penyajian data, dan verifikasi (menarik kesimpulan). Berikut ini akan disajikan indikator kreativitas seni pada anak usia dini.

Tabel 1. Indikator Kreativitas Seni Anak

\begin{tabular}{|c|c|}
\hline Indikator & Sub Indikator \\
\hline $\begin{array}{lr}1 . & \text { Kemampuan anak } \\
\text { untuk } & \text { mengembangkan } \\
\text { kreativitas } & \text { seni melalui sebuah } \\
\text { permainan }\end{array}$ & $\begin{array}{l}\text { a. Anak dapat menciptakan } \\
\text { sebuah karya melalui permainan } \\
\text { kolase ampas kelapa } \\
\text { b. Anak } \\
\text { menyelaraskan dan memadukan } \\
\text { warna dalam penempelan kolase } \\
\text { ampas kelapa }\end{array}$ \\
\hline $\begin{array}{llr} & \text { Melatih } & \text { kesabaran } \\
\text { anak } & \text { saat } & \text { memainkan } \\
\text { permainan } & \end{array}$ & $\begin{array}{l}\text { a. Anak melakukan dengan } \\
\text { teliti dan sabar saat menaburkan } \\
\text { bahan kolase pada kerta bergambar } \\
\text { b. Anak menyelesaikan } \\
\text { permainan sesuai petunjuk yang } \\
\text { diarahkan }\end{array}$ \\
\hline $\begin{array}{l}\text { 3. Kemampuan } \\
\text { mengenal warna }\end{array}$ & 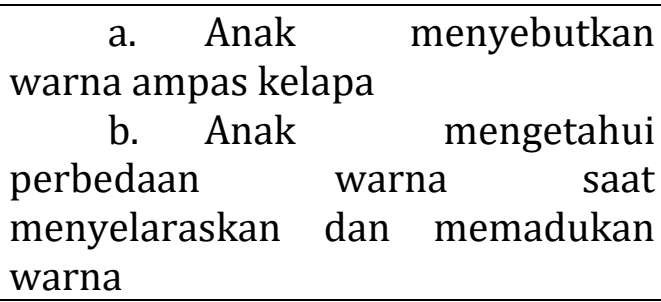 \\
\hline $\begin{array}{l}\text { 4. Menunjukkan sikap } \\
\text { kemandirian }\end{array}$ & $\begin{array}{l}\text { a. Anak mampu berbagi } \\
\text { mainan bersama temannya } \\
\text { b. Dapat membersihkan } \\
\text { dan menyusun kembali mainan }\end{array}$ \\
\hline
\end{tabular}

\section{Hasil dan Pembahasan}

Adapun hal yang dianalisi pada penelitian ini yaitu peningkatan kreativitas anak melalui permainan kolase ampas kelapa. Berdasarkan observasi, wawancara dan dokumentasi pada PAUD Al-Faiz Paya Bujok Tunong Langsa diperoleh data sebagai berikut:

\subsection{Tahap pertama observasi}

Guru dan siswa berinteraksi dengan baik terlihat pada proses pembelajaran. Dimana terlebih dahulu guru mengarahkan anak sebelum 
memulai proses pembelajaran melalui permainan kolase ampas kelapa. Pada proses pembelajaran guru menciptakan suasana menyenangkan, nyaman dan aman bagi anak.

Anak sudah tidak lagi meniru atau mencontoh karya seni dari teman disebelahnya. Mereka mulai berkreasi menurut yang mereka pikirkan secara bebas dengan menyelarasakan atau memadukan warna pada ampas kelapa dan mulai menaburi dan menempel ampas kelapa pada gambar yang disediakan guru. Anak juga tampak dengan teliti saat menaburi ampas kelapa tersebut ada beberapa ketertarikan anak saat melakukan kegiatan ini diataranya terletak pada warna dari pada ampas kelapa itu sendiri. Ampas kelapa sengaja diberi warna dengan berbagai macam warna agar meningkatkan minat anak saat melakukan kegiatan pembelajaran. Dari penjabaran diatas dapat dilihat perkembangan kreativitas anak di Paud AlFaiz Kota Langsa.

\subsection{Tahap Kedua Wawancara}

Wawancara dijadikan alat untuk mengumpulkan data berbeda dengan observasi yang hanya melihat. Saat wawancara ini lebih kepada tanya jawab dengan pihak sekolah atau guru kelas untuk mengetahui secara jelas peningkatan kreativitas seni anak. Pertanyaan yang akan dijadikan panduan dalam pengumpulan data dan diantara pertanyaannya adalah sebagai berikut: Pada poin pertama penulis menanyakan Langkah-langkah yang dilakukan dalam mempersiapkan media pembelajaran kolase gambar dengan menggunakan ampas kelapa.

Tahapan awal guru mempersiapkan media pembelajaran yang akan diberikan kepada anak seperti, buku gambar yang sudah digambarkan bentuk benda oleh guru, lem dan juga ampas kelapa. dalam tahap ini sebelum guru memberikan contoh cara bermain kepada anak. Guru bertanya terlebih dahulu tentang warna-warna yang terdapat pada ampas kelapa agar anak dapat mengenali warna. Tahap pertama guru mengawali dengan 
memberikan salam kepada anak-anak yang berada didalam ruangan kelas setelah itu guru langsung memperkenalkan media pembelajaran yang akan dilakukan sebelumnya guru melakukan Tanya jawab dengan anak terkait tema pembelajaran pada hari tersebut. Setelah mengetahui tema pembelajaran guru menampilkan gambar yang sesuai dengan tema pembelajaran pada hari itu yaitu anggota kelurgaku. Setelah itu guru menanyakan kepada anak apakah mereka mengetahu gambar apa yang sedang diperlihatkan itu. Anak-anak sontak langsung menjawab bersama anggota keluargaku, gurupun memberikan pujian. Dan setelah itu guru langsung masuk dalam tahap penjelasan materi.

Tahapan kedua yaitu bagaimana guru dalam menjelaskan kegiatan permainan yang akan dilakukan?. Dimana guru memberikan penjelasan terkait permainan yang akan dikerjakan. Guru mengambil sebuah kertas yang berisikan gambar rumah yang menjadi tujuan dalam pembelajaran. Selanjutnya mengarahkan gambar tersebut kearah anak dan kemudian mengoleskan lem secara perlahan sambil memberi penjelasan kepada anak agar anak paham dengan metode yang akan dikerjakan. Anak pun memperhatikan dengan seksama. Setelah mengoleskan lem secara merata gurupun mengambil ampas kelapa dengan tiga macam warna tersebut diantaranya ada merah, kuning, dan hijau. Lalu guru mengambil warna merah yang ditaburkan perlahan di gambar anggota keluarga, baru kemudian mengambil warna kuning untuk bagian badan dan terkhir warna hijau untuk bagian kaki.

Guru memberikan penjelasan kepada anak terkait dengan permainan dengan meperkenalkan ampas kelapa, asal mula ampas kelapa dan manfaat dari ampas kelapa tersebut sehingga anak dapat memahami bahwa tidak semua barang bekas itu dikatakan sampah. Karena tanpa kita sadari sangat banyak manfaat dari barang bekas diantaranya ampas kelapa dapat dijadikan sebgai media pembelajaran yang aman bagi anak dan mudah didapatkan. Setelah itu guru mempraktekkan cara bermainnya. 
Tahapan ketiga Apa saja kendala yang terjadi saat melakukan permainan kolase dengan ampas kelapa ? Ada beberapa kendala yang ditemui guru saat melakukan kegiatan permainan kolase dengan menggunakan ampas kelapa ini. Diantaranya adalah ada anak yang tidak sabar dalam menunggu giliran main. Bahwa antusias anak saat memainkan kegiatan kolase ampas kelapa ini sangatlah luar biasa. Anak memiliki ketertarikan tersendiri saat melihat media permainan dibuat dari ampas kelapa yang di campurkan warna menjadi tiga warna. campurkan warna menjadi tiga warna. Hal ini menjadi tantangan tersendiri bagi guru untuk menenangkan anak dan juga memberikan arahan kepada anak agar mau bersabar menunggu giliran. Dan yang terakhir point keempat. Bagaimana praktek dalam permainan kolase dengan menggunakan ampas kelapa.

Setelah guru memberikan contoh cara bermain kepada anak. Maka berikan instruksi pada anak agar mengkreasikan taburan kolase dengan beberapa warna yang disukai anak. dan setelah itu dapat dilihat bagaimana anak dapat menciptakan sebuah karya dengan menggunakan ampas kelapa. Disaat mengerjakan kegiatan kolase guru dapat melihat berbagai macam warna dan kreativitas anak dalam menyelaraskan warna dengan menggunakan permainan kolase dengan menggunakan ampas kelapa. Anak tampak sangat menyenangi kegiatannya. Berdasarkan observasi dan wawancara di PAUD Al-Faiz Desa Paya Bujok Tunong Langsa dapat dilihat bahwa perkembangan kreativitas anak mulai meningkat. Hal ini dapat diketahui dari beberapa lembar tes dan kisi-kisi wawancara yang dilakukan peneliti terhadap guru dan anak. Dan pada akhirnya mendapati hasil yang memuaskan dan sesuai indikator-indikator penelitian yang di lakukan peneliti dalam penelitian ini.

Terakhir point keempat. Bagaimana praktek dalam permainan kolase dengan menggunakan ampas kelapa. Setelah guru memberikan contoh cara bermain kepada anak. Maka berikan instruksi pada anak agar mengkreasikan taburan kolase dengan beberapa warna yang disukai anak. dan setelah itu 
dapat dilihat bagaimana anak dapat menciptakan sebuah karya dengan menggunakan ampas kelapa

Setelah mengerjakan kegiatan kolase guru dapat melihat berbagai macam warna dan kreativitas anak dalam menyelaraskan warna dengan menggunakan permainan kolase dengan menggunakan ampas kelapa. Anak tampak sangat menyenangi kegiatannya. Berdasarkan observasi dan wawancara di Paud Al- Faiz Kota Langsa dapat dilihat bahwa perkembangan kreativitas anak mulai meningkat. Hal ini dapat diketahui dari beberapa lembar tes dan kisi-kisi wawancara yang dilakukan peneliti terhadap guru dan anak. Dan pada akhirnya mendapati hasil yang memuaskan dan sesuai indikator-indikator penelitian yang di lakukan peneliti dalam penelitian ini.

Jadi dapat dipaparkan secara keseluruhan hal-hal yang berkaitan dari awal sampai akhir penelitian, maka data yang diperoleh yaitu: berdasarkan hasil observasi pra penelitian dalam keselarasan warna saat menempel ampas kelapa anak belum berkembang dikarenakan anak belum dapat membedakan warna dengan benar. Maka dari itu anak masih kesulitan dalam

memandukan warna. Awal kegiatan menempel kolase ampas kelapa kreativitas belum berkembang dikarenakan anak masih tidak sabar dalam menaburkan ampas kelapa pada gambar. Akibatnya tempelan kolase anak menjadi kurang rapi dan masih kurang indah saat dilihat.

Pengenalan warna anak melalui ampas kelapa, anak masih sulit menyebutkan warna saat guru menanyakan tentang macam-macam warna yang terdapat pada ampas kelapa dan anak juga masih kesulitan dalam membedakan warna. Anak mengetahui nama dari warna tersebut, akan tetapi anak masih tidak tahu mana warna yang disebutkan. Melatih sikap mandiri anak saat berbagi dengan teman dan membereskan mainan setelah kegiatan. Pada tahapan ini anak belum dapat berbagi dengan teman saat melakukan kegiatan anak masih egois dan tidak mau bersabar saat berbagi ampas kolase dengan teman sekelasnya saat melakukan kegiatan. 
Hasil penelitian dapat diketahui Keselarasan warna saat menempel ampas kelapa dan kerapian anak saat menempel ampas kelapa(Seni) meningkat secara bertahap. Dari setiap anak guru memberikan contoh gambar anggota keluarga anak mengikuti apa yang diminta oleh peneliti sebagai berikut:

a. Responden 1 dengan indikator keselarasan warna saat menempel kolase dengan menggunakan ampas kelapa dan kerapian anak saat menempel 1 anak Mulai Berkembang (MB) .

b. Responden 2 dengan indikator keselarasan warna saat menempel kolase dengan menggunakan ampas kelapa dan kerapian anak saat menempel 1 anak Berkembang Sesuai Harapan(BSH)

c. Responden 3 dengan indikator keselarasan warna saat menempel kolase dengan menggunakan ampas kelapa dan kerapian saat menempel 8 anak Berkembang Sangat Baik (BSB)

Hasil penelitian pengenalan warna melalui ampas kelapa (Kognitif) mendapatkan peningkatan secara bertahap. Ini dilihat dari bagaimana anak mulai memahami dan dapat menyebutkan serta membedakan warna . Diantaranya sebagai berikut:

a. Responden 1 dengan indikator pengenalan warna anak melalui ampas kelapa 2 anak yang Mulai Berkembang (MB).

b. Responden 2 dengan indikator pengenalan warna anak melalui ampas kelapa 2 anak yang Berkembang Sesuai Harapan(BSH)

c. Responden 3 dengan indikator pengenalan warna anak melalui ampas kelapa 6 anak Berkembang Sesuai Harapan(BSB)

Melatih sikap mandiri anak saat berbagi dengan teman dan membereskan mainan setelah kegiatan mendapatkan peningkatan secara bertahap. Hal ini dilihat saat anak melakukan kegiatan mengkolase anak dapat berbagi dan saling menolong sesame teman dan membantu ibu guru membereskan mainan setelah kegiatan. Di antaranya sebagai berikut: 
a. Responden 1 dengan indikator melatih sikap mandiri anak saat berbagi dengan teman dan membereskan mainan setelah kegiatan 3 anak Mulai Berkembang (MB)

b. Responden 2 dengan indikator melatih sikap mandiri anak saat berbagi dengan teman dan membereskan mainan setelah kegiatan 2 anak Berkembangan Sesuai Harapan (BSH).

c. Responden 3 dengan indikator melatih sikap mandiri anak saat berbagi dengan teman dan membereskan mainan setelah kegiatan 3 anak Berkembangan Sangat Baik (BSB).

\section{KESIMPULAN}

Berdasarkan observasi, wawancara dan dokumentasi yang dilaksanakan di PAUD Al-Faiz Tunong Kota Langsa. Dilihat dari tes akhir anak terdapat perkembangan diantaranya didalam bidang seni dengan indikator keselarasan warna belum berkembang 0 anak (0\%), kemampuan Meyelaraskan warna mulai berkembang 2 anak (20\%), kemampuan menyelaraskan warna berkembang sesuai harapan 3 anak (30\%), kemampuan menyelaraskan warna 5 anak (50\%).

Hasil menunjukkan bahwa terdapat peningkatan dalam perkembangan kreativitas anak saat menyelaraskan warna saat memainkan kolase dengan menggunakan ampas kelapa. Pada penelitian poin kedua perkembangan bahasa dalam pengenalan warna yang terdapat pada ampas kelapa belum berkembang 0 anak (0\%), perkembangan bahasa mulai berkembang 3 anak (30\%), perkembangan bahasa anak berkembang sesuai harapan 2 anak (20\%), perkembangan bahasa 5 anak (50\%). Hasil menunjukkan bahwa kemampuan kreativitas seni anak mulai berkembang dengan baik. Dan poin ketiga perkembangan social emosional anak dalam sikap mandiri anak belum berkembang 2 anak (20\%), perkembangan sikap mandiri anak mulai berkembang 3 anak (30\%), perkembangan sikap mandiri anak berkembang sesuai harapan 2 anak (20\%) perkembangan sikap mandiri anak berkembang sangat baik 3 anak (30). 
Kesimpulan yang dapat dijadikan hasil dari pada tes akhir permainan kolase gambar dengan menggunakan ampas kelapa ini yaitu. Terdapat peningkatan kreativitas seni anak saat memainkan permainan kolase gambar ini. Hal ini dapat dilihat banyak anak yang sudah mulai mampu mengerjakan kegiatan sesuai intruksi guru dan saat melakukan kegiatan $90 \%$ anak mampu mengerjakan sesuai dengan indikator.

PAUD Al-Faiz Kota Langsa tidak semata-mata hanya mengajarkan pembelajaran mewarnai saja terhadap anak. akan tetapi guru membuat inovasi baru yaitu dengan menggunakan ampas kelapa sebagai media dalam pembelajaran agar anak tidak jenuh dan bosan saat melakukan kegiatan pembelajaran.

Selanjutnya tahap awal guru mempersiapkan media pembelajaran yang akan diberikan kepada anak seperti, buku gambar yang sudah digambarkan bentuk benda oleh guru, lem dan juga ampas kelapa. Sebelum guru memberikan contoh cara bermain kepada anak. Guru bertanya terlebih dahulu tentang warna-warna yang terdapat pada ampas kelapa agar anak dapat mengenali warna. Selanjutnya guru mengawali dengan memberikan salam kepada anak-anak yang berada didalam ruangan kelas setelah itu guru langsung memperkenalkan media pembelajaran yang akan dilakukan sebelumnya guru melakukan tanya jawab dengan anak terkait tema pembelajaran pada hari tersebut. Setelah mengetahui tema pembelajaran guru menampakkan sebuah gambar yang sesuai dengan tema pembelajaran pada hari itu yaitu (anggota kelurgaku). Setelah itu guru menanyakan kepada anak apakah mereka tahu gambar apa yang sedang diperlihatkan itu. Anakanak sontak langsung menjawab bersama (anggota keluargaku) gurupun memberikan pujian. Dan setelah itu guru langsung masuk dalam tahap penjelasan materi.

Tahapan berikutnya guru dalam menjelaskan kegiatan permainan yang akan dilakukan. Guru memberikan penjelasan terkait permainan yang akan dikerjakan. Guru mengambil sebuah kertas yang berisikan gambar rumah 
yang menjadi patokan dalam pembelajaran. Lalu, mengarahkan gambar tersebut kearah anak dan kemudian mengoleskan lem secara perlahan sambil memberi penjelasan sedikit kepada anak agar anak paham dengan metode yang akan dikerjakan. Anak pun memperhatikan dengan seksama. Setelah mengoleskan lem secara merata gurupun mengambil ampas kelapa dengan tiga macam warna tersebut diantaranya ada merah, kuning, dan hijau guru mengambil warna merah yang ditaburkan perlahan di gambar anggota keluarga, baru kemudian mengambil warna kuning untuk bagian badan dan terkhir warna hijau untuk bagian kaki.

Guru memberikan penjelasan kepada anak terkait dengan permainan dengan meperkenalkan ampas kelapa, asal muasal ampas kelapa dan manfaat dari ampas kelapa tersebut sehingga anak dapat memahami bahwa tidak semua barang bekas itu dikatakan sampah. Karena tanpa kita sadari sangat banyak manfaat dari barang bekas diantaranya ampas kelapa dapat dijadikan sebgai media pembelajaran yang aman bagi anak dan mudah didapatkan. Setelah itu guru mempraktekkan cara bermainnya.

Poin selanjutnya kendala yang terjadi saat melakukan permainan kolase dengan ampas kelapa. Ada beberapa kendala yang ditemui guru saat melakukan kegiatan permainan kolase dengan menggunakan ampas kelapa ini. Dianataranya adalah anak yang tidak sabar dalam menunggu giliran main. Seperti yang penulis uraikan sebelumnya. Bahwa antusias anak saat memainkan kegiatan kolase ampas kelapa ini sangatlah luar biasa. Anak memiliki ketertarikan tersendiri saat melihat media permainan dibuat dari ampas kelapa yang di campurkan warna menjadi tiga warna. Hal ini menjadi tantangan tersendiri bagi guru untuk menenangkan anak dan juga memberikan arahan kepada anak agar mau bersabar menunggu giliran. Akan tetapi semua itu dapat terbalas dengan meningkatkan kreativitas anka usia dini.

Point keempat. Bagaimana praktek dalam permainan kolase dengan menggunakan ampas kelapa. Setelah guru memberikan contoh cara bermain 
kepada anak. Maka berikan instruksi pada anak agar mengkreasikan taburan kolase dengan beberapa warna yang disukai anak. dan setelah itu dapat dilihat bagaimana anak dapat menciptakan sebuah karya dengan menggunakan ampas kelapa.

\section{E. Saran}

1) Bagi guru diharapkan agar lebih kreatif dalam membuat media pembelajaran yang dapat memicu peningkatan kreativitas anak. karena anak usia dini itu merupakan masa keemasana anak dimana pada masa ini anak lebih berpotensi dalam meningkatkan mutu dan kualitas dan sudah menjadi tugas guru menjadi fasilitator bagi anak.

2) Bagi pembaca sebagai referensi bacaan dalam mengembangkan mediamedia pembelajaran khususnya yang mengacu pada kreativitas agar dapat menciptakan anak-anak usia dini yang memiliki karya seni cipta yang tinggi.

\section{DAFTAR PUSTAKA}

Fadhillah. (2017). Buku Ajar Bermain Anak. Jakarta: Kencana.

Mulyasa. (2012). Manajemen Paud. Bandung : PT. Muda Rosdakarya.

Mursid. (2015). Belajar Dan Pembelajaran PAUD. Bandung: PT. Remaja Rosdakarya.

Noor, D. J. (2016). Metodologi Penelitian. Jakarta: Prenada Media.

R Moeslichatoen R. (2014). Metode Pengajaran di Taman Kanak-Kanak,. Jakarta : Rineka Cipta.

Supriyenti, A. (2013). Meningkatkan Kreativitas Seni Rupa Anak Melalui Kegiatan Mencetak Dengan Bahan Alam di Paud Aisyiyah Lansano Pesisir Selatan. Spektrum PLS , 16. 